\title{
The Alzheimer Amyloid Precursor Is Associated with the Detergent-insoluble Cytoskeleton
}

\author{
Lawrence M. Refolo, ${ }^{1,2}$ Ian S. Wittenberg, ${ }^{1,2}$ Victor L. Friedrich, Jr., ${ }^{2,3}$ and Nikolaos K. Robakis ${ }^{1,2}$ \\ 'Department of Psychiatry, ${ }^{2} F i s h b e r g$ Research Center for Neurobiology, and ${ }^{3}$ Brookdale Center for Molecular Biology, \\ Mount Sinai School of Medicine, New York, New York 10029
}

The amyloid $\beta$-protein (A $\beta \mathrm{P}$ ), the main component of neuritic plaques in Alzheimer's disease (AD), is derived by unknown mechanisms from a family of amyloid precursor proteins (APPs). Using a detergent extraction procedure, we have found that in brain and in neural cell lines, 50-90\% of APP is bound to detergent-insoluble cytoskeleton. Labeling experiments performed in a $\mathbf{C 6}$ glioma cell line indicated that both cell surface and intracellular APPs are associated with the cytoskeleton. This association requires intact microtubules and is modulated by protein phosphorylation and by cell density. These findings suggest that the function of cellular APP, presently unknown, involves the cytoskeleton and particularly microtubules. The dynamic nature of the binding and its dependence on microtubules and protein phosphorylation suggest it as a possible target in $A D$, where abnormal cytoskeletal structures and protein phosphorylation have been reported. Altered cytoskeletal binding of APP might lead to its aberrant proteolysis and generation of the $A \beta P$.

Alzheimer's disease (AD) is a common neurodegenerative disorder characterized by the presence of extracellular neuritic plaques, vascular amyloid, and intracellular neurofibrillary tangles in the brains of affected individuals. The major component of the neuritic plaque core is the amyloid $\beta$-protein $(\mathrm{A} \beta \mathrm{P})$, which is part of at least three distinct amyloid precursor proteins (APPs) containing $770\left(\mathrm{APP}_{770}\right), 751\left(\mathrm{APP}_{751}\right)$, and $695\left(\mathrm{APP}_{695}\right)$ amino acids, respectively (Goldgaber et al., 1987; Kang et al., 1987; Robakis et al., 1987; Tanzi et al., 1987, 1988; Kitaguchi et al., 1988; Ponte et al., 1988). Full-length APPs are ubiquitously expressed integral membrane glycoproteins with a large extracellular region, a transmembrane sequence, and a small cytoplasmic domain (Kang et al., 1987; Robakis et al., 1987). In addition, secreted APP forms containing only a portion of the $A \beta P$ sequence have been detected (Esch et al., 1990; Anderson et al., 1991). APPs undergo extensive posttranslational modifications including glycosylation, sulfation, and phosphorylation and on SDS gels appear as a family of proteins migrating between 105 and $140 \mathrm{kDa}$ (Refolo et al., 1989; Schubert et al., 1989; Weidemann et al., 1989; Oltersdorf et al., 1990). The secreted forms have been reported to display growth-promoting activity

Received May 1, 1991; revised July 12, 1991; accepted July 22, 1991

We thank M. Maniatis for her assistance with the cell cultures, and Drs. L. Binder, P. Nissley, and P. Srivastava for antibodies. This work was supported by NIH Grants AG08200 and AG05138.

Correspondence should be addressed to Dr. Nikolaos K. Robakis, Department of Psychiatry and Fishberg Research Center for Neurobiology, Box 1229, Mount Sinai School of Medicine, One Gustave Levy Place, New York, NY 10029-6574. Copyright (C) 1991 Society for Neuroscience $0270-6474 / 91 / 113888-10 \$ 05.00 / 0$ and may play a role in blood coagulation (Saitoh et al., 1989; Smith et al., 1990), but the specific biological functions of the transmembrane APPs are not known. The mechanism(s) that generate $\mathrm{A} \beta \mathrm{P}$ from the full-length APPs, presently unknown, might be clarified by detailed information concerning the cellular function(s) of APP. Recently, we presented immunocytochemical data suggesting a cytoskeletal association for APP epitopes in primary cultures of rat neuroglia (Berkenbosch et al., 1990). Several other intrinsic membrane proteins, including integrins, cadherins, and N-CAM (Pollerberg et al., 1987; Burridge et al., 1988; Nelson et al., 1990) have also been shown to be associated with the cytoskeletal fraction of the cell. These studies have relied on extraction of cell cultures in the presence of nonionic detergents under conditions that stabilized cytoskeletal structures. Proteinaceous structures stabilized by protein-protein interactions resist solubilization by these detergents and thus can be separated from the soluble membranes. Cytoskeletons from erythrocytes (Yu et al., 1973) and junctional complexes (Gorbsky and Steinberg, 1981) have also been isolated using this approach. Using a similar methodology, we demonstrate that APP is associated with the detergent-insoluble cytoskeleton and that this association requires intact microtubules. Furthermore, the cytoskeletal anchorage of APP is modulated by cell density and by protein phosphorylation.

\section{Materials and Methods}

\section{Cell cultures}

The rat C6 glioma cell line (Benda et al., 1968) was obtained from the American Type Culture Collection (ATCC), Rockville, MD. Cultures were seeded at $1.5 \times 10^{4}$ cells $/ \mathrm{mm}^{2}$ onto $100 \mathrm{~mm}$ plastic tissue culture dishes (Corning) and maintained in Dulbecco's modified Eagle's Medium (DME) supplemented with $10 \%$ fetal bovine serum. Cell density was determined by trypsinizing and counting parallel cultures.

PC1 2 cells were obtained from the ATCC and were maintained in RPMI 1640 medium supplemented with $10 \%$ horse and $5 \%$ fetal bovine sera. Neuronal PC12 cultures were obtained as described in Greene and Tischler (1976). Cells were seeded onto collagen-coated plates at a density of $5 \times 10^{4}$ cells $/ \mathrm{mm}^{2}$ and after $24 \mathrm{hr}$ were treated with $50 \mathrm{ng} / \mathrm{ml}$ $\beta$ NGF (R. Stach, University of Michigan). The cultures were maintained for $7 \mathrm{~d}$, and the NGF-containing medium was changed every $48 \mathrm{hr}$.

\section{Preparation of detergent-soluble and cytoskeletal fractions}

Detergent-soluble and -insoluble fractions were prepared by the method of Wilson and Brophy (1989). Cell cultures were washed two times with PBS containing $\mathrm{Ca}^{2+}$ and $\mathrm{Mg}^{2+}$ and one time with CSK buffer (Wilson and Brophy, 1989) containing $10 \mathrm{~mm}$ 1,4-piperazinediethanesulfonic acid, $\mathrm{pH} 6.9,50 \mathrm{~mm} \mathrm{KCl}, 2 \mathrm{~mm}$ EGTA, $1 \mathrm{~mm} \mathrm{MgCl} 2,2 \mathrm{~m}$ glycerol, 1.0 mm phenylmethylsulfonyl fluoride (PMSF), $25 \mu \mathrm{g} / \mathrm{ml}$ leupeptin, $25 \mu \mathrm{g}$ $\mathrm{ml}$ pepstatin, and $50 \mu \mathrm{g} / \mathrm{ml}$ aprotinin. Subsequently, the cultures were extracted for $5 \mathrm{~min}$ at room temperature with CSK buffer containing $0.5 \%$ Triton X-100 (buffer A). The detergent solution was aspirated off the cultures and centrifuged at room temperature at $15,000 \times g$ for 10 
min. This supernatant is referred to as the detergent-soluble fraction. The remaining cell residue was scraped off the culture dishes using 2.0 $\mathrm{ml}$ per dish of CSK buffer. This material was transferred to a Dounce vessel and homogenized, on ice, with three strokes of a loosc-fitting pestle. The homogenate was centrifuged in the cold at $10,000 \times g$ for $15 \mathrm{~min}$, and the detergent-insoluble pellet was resuspended in $0.25 \mathrm{ml}$ of solubilization buffer containing $50 \mathrm{~mm}$ Tris, $\mathrm{pH} 7.4,10 \mathrm{~mm}$ EGTA, 10 mм EDTA, $100 \mathrm{~mm} \mathrm{NaCl}, 1 \%$ SDS, 1 mM PMSF, $25 \mu \mathrm{g} / \mathrm{ml} \mathrm{leupeptin,}$ $25 \mu \mathrm{g} / \mathrm{ml}$ pepstatin, and $50 \mu \mathrm{g} / \mathrm{ml}$ aprotinin. The resuspension was passed several times through a 22 gauge needle, boiled for $10 \mathrm{~min}$, and centrifuged at $15,000 \times g$ at room temperature for $10 \mathrm{~min}$. The supernatant was saved and is referred to as the detergent-insoluble cytoskeletal fraction. Protein determinations were obtained by the Pierce BCA assay (Smith et al., 1985). Some cultures were extracted with TNE buffer containing $50 \mathrm{~mm}$ Tris- $\mathrm{Cl}, \mathrm{pH} 8.0,150 \mathrm{~mm} \mathrm{NaCl}$, and $2 \mathrm{~mm}$ EDTA in the presence of $0.5 \%$ Triton X-100.

Detergent-soluble and cytoskeletal fractions were prepared from adult Sprague-Dawley rat brain tissue. Whole brains were frozen in liquid nitrogen and crushed to a fine powder using a mortar and pestle. This material was mechanically homogenized, at room temperature, with five strokes of the Potter-Braun homogenizer in 10 vol of buffer A. The homogenate was centrifuged at $15,000 \times g$ for $30 \mathrm{~min}$, yielding a detergent-soluble supernatant and a detergent-insoluble cytoskeletal pellet. The pellet derived from $2 \mathrm{gm}$ of brain tissue was resuspended in $2.0 \mathrm{ml}$ of Tris/SDS solubilization buffer, passed several times through a 22 gauge needle, and boiled for $10 \mathrm{~min}$. Subsequently, the homogenate was centrifuged at $15,000 \times g$ for $15 \mathrm{~min}$, and the resulting supernatant is referred to as the detergent-insoluble cytoskeletal fraction.

\section{Immunochemical reagents}

Anti-R1, antiserum directed against amino acids 673-695 of $\mathrm{APP}_{695}$, was prepared and used as described (Anderson et al., 1989; Refolo et al., 1989).

Antisera raised against the following proteins were used: $\beta$-tubulin $5 \mathrm{H} 1$ provided by L. Binder (University of Alabama); mannose-6-phosphate receptor provided by $P$. Nissley (NIH); gp96 provided by $P$. Srivastava (Mt. Sinai). Antiserum against actin was obtained from Amersham. Antibodies against glial fibrillary acidic protein (GFAP), neurofilament subunit $M$, nerve growth factor receptor (NGFR), synapsophysin, and secretogranin B were obtained from Boehringer Mannheim. Anti- $\mathrm{Na}^{+} / \mathrm{K}^{+}-$ATPase was obtained from Cal Biochemicals.

\section{Immunoblots}

Immunoblots were performed as previously described (Anderson et al., 1989). In brief, $100 \mu \mathrm{g}$ of protein from each sample were loaded per lane and run on SDS-polyacrylamide gels (Laemmli, 1970). Separated proteins were transferred electrophoretically to Immobilon filters (Millipore) that were then pretreated overnight in Tris-buffered saline (TBS; $50 \mathrm{~mm}$ Tris- $\mathrm{HCl}, \mathrm{pH} 8.0,150 \mathrm{~mm} \mathrm{NaCl}$ ), containing $0.1 \%$ Tween 20 and $10 \%$ newborn calf serum (NCS). The filters were probed for $1 \mathrm{hr}$ at room temperature, with the appropriate primary antibody diluted in TBS-NCS containing $0.1 \%$ Tween 20 . Subsequently, the filters were washed for $1 \mathrm{hr}$ with TBS-0.1\% Tween and incubated for $1 \mathrm{hr}$ with either an ${ }^{125} I$ anti-rabbit or an ${ }^{125} I$ anti-mouse (Amersham) secondary antibody, diluted in TBS-NCS. The filters were given a final $1 \mathrm{hr}$ wash in TBS- $0.1 \%$ Tween and autoradiographed. Signal was quantitated by densitometry.

\section{Signal quantitation}

Signals from each lane, corresponding to $100 \mu \mathrm{g}$ of loaded protein, were quantitated by soft laser densitometry. Since the total protein content of soluble and cytoskeletal fractions differs, the percentage of total APP in each fraction was determined as follows. The area corresponding to the signal from $100 \mu \mathrm{g}$ of protein was used to calculate the signal area corresponding to the total protein in each fraction. The percentage of total APP in each fraction was then determined by dividing the signal area of each fraction by the sum of the signal areas of both fractions times 100 . Each determination was the average of at least two independent experiments.

\section{Cell surface labeling}

C6 glioma cultures were labeled by the lactoperoxidase-catalyzed iodination using a previously published procedure (Hubbard and Cohn,
1976). Plates containing approximately $5 \times 10^{5}$ cells $/ \mathrm{mm}^{2}$ were washed three times with cold PBS containing $\mathrm{Mg}^{2+}$ and $\mathrm{Ca}^{2+}$. All subsequent steps were performed between $4^{\circ} \mathrm{C}$ and $10^{\circ} \mathrm{C}$ to limit the nonspecific internalization of $\mathrm{Na}^{125}$. Each $100 \mathrm{~mm}$ plate received $2.0 \mathrm{ml}$ of PBS $\left(\mathrm{Mg}^{2+} / \mathrm{Ca}^{2+}\right)$ containing $1 \mathrm{mCi}$ of $\mathrm{Na}{ }^{125} \mathrm{I}$ (Amersham). The iodination was initiated by adding $20 \mu \mathrm{l}$ of a $2 \mathrm{mg} / \mathrm{ml}$ solution of lactoperoxidase (Sigma), followed by $20 \mu \mathrm{l}$ of $0.03 \%$ hydrogen peroxide. The reaction was allowed to proceed for $30 \mathrm{~min}$, with the addition of fresh aliquots of lactoperoxidase and hydrogen peroxide every $10 \mathrm{~min}$. At the appropriate time, the plates were washed three times with $\mathrm{PBS}\left(\mathrm{Mg}^{2+} / \mathrm{Ca}^{2+}\right)$ containing $5 \mathrm{~mm}$ potassium iodide. The plates were then subjected to extraction in CSK buffer containing $0.5 \%$ Triton X-100 (buffer A), followed by preparation of detergent-soluble and cytoskeletal fractions. Trypsinization of labeled cells was performed by incubating cell cultures with $50 \mu \mathrm{g} / \mathrm{ml}$ trypsin in DME without serum, for $30 \mathrm{~min}$ at room temperature. At the appropriate time, soybean trypsin inhibitor was added to each plate to a final concentration of $1 \mathrm{mg} / \mathrm{ml}$. Following a 5 min incubation at room temperature, the trypsinized plates were extracted with buffer A as previously described.

\section{Immunoprecipitations}

Radiolabeled cell extracts prepared as described above were used for immunoprecipitations. Each sample containing about $3 \times 10^{6}$ of trichloroacetic acid (TCA) precipitable counts was made $1 \times$ in IL buffer (50 mM Tris- $\mathrm{HCl}, \mathrm{pH} 7.2,150 \mathrm{~mm} \mathrm{NaCl}, 5 \mathrm{~mm}$ EDTA, $0.2 \%$ Triton $\mathrm{X}-100$ ) containing $2 \mathrm{mM}$ PMSF, $20 \mu \mathrm{g} / \mathrm{ml}$ leupeptin, $20 \mu \mathrm{g} / \mathrm{ml}$ pepstatin, and $50 \mu \mathrm{g} / \mathrm{ml}$ aprotinin, and then "precleared" for $30 \mathrm{~min}$ at $4^{\circ} \mathrm{C}$ using $30 \mu \mathrm{l}$ of protein A-Sepharose. The precleared samples were incubated at $4^{\circ} \mathrm{C}$ overnight, with agitation, in the presence of the appropriate antibodies. Antigen-antibody complexes were recovered by the addition of $30 \mu \mathrm{l}$ of protein A-Sepharose, followed by incubation, with agitation, at $4^{\circ} \mathrm{C}$ for $30 \mathrm{~min}$. The immunoprecipitates were collected by centrifugation and washed three times with $1 \times$ IL buffer. Laemmli sample buffer, containing 5\% 2-mercaptoethanol, was added to the washed beads, and the samples were boiled for $5 \mathrm{~min}$. The samples were resolved by SDS-PAGE (Laemmli, 1970).

\section{Cell density experiments}

Variations in cell density was achieved by two different methods.

Method 1. For low-density cultures, C6 cells were seeded in $60 \mathrm{~mm}$ plates at a density of $1.30 \times 10^{2}$ cells $/ \mathrm{mm}^{2}$. After approximately $24 \mathrm{hr}$, five plates were trypsinized, counted, and found to contain approximately $3.8 \times 10^{2}$ cells $/ \mathrm{mm}^{2}$. Low-density cultures (10 plates) were sequentially extracted with buffer $A$ as described above, except that the volume of buffer per plate was $0.3 \mathrm{ml}$.

For high-density cultures, $\mathrm{C} 6$ cells were seeded onto $100 \mathrm{~mm}$ plates at an initial density of $1.9 \times 10^{2}$ cells $/ \mathrm{mm}^{2}$. These cultures were maintained as described above for $5 \mathrm{~d}$. At this time, the cultures were counted and found to have approximately $6.3 \times 10^{3} \mathrm{cells} / \mathrm{mm}^{2}$. Five plates of these cultures were extracted with $2.0 \mathrm{ml} /$ plate of buffer A. The detergent-to-protein ratio for the extraction of both high- and low-density cultures was about 5:1.

Method 2. For low-density cultures, C6 cells were seeded onto $60 \mathrm{~mm}$ plates at 50 cells $/ \mathrm{mm}^{2}$. These cultures were maintained in DME $/ 10 \%$ fetal calf serum for $4 \mathrm{~d}$, at which time they contained $6 \times 10^{2}$ cells/ $\mathrm{mm}^{2}$. Ten low-density plates were extracted sequentially with $0.5 \mathrm{ml}$ of buffer $\mathrm{A}$.

High-density cultures were obtained by seeding $100 \mathrm{~mm}$ plates at 8 $\times 10^{2}$ cells $/ \mathrm{mm}^{2}$. The cultures were maintained for $4 \mathrm{~d}$, at which time their density was approximately $7 \times 10^{3} \mathrm{cells} / \mathrm{mm}^{2}$. Five high-density cultures were extracted sequentially with $2.0 \mathrm{ml}$ of buffer $\mathrm{A}$. The detergent to protein ratio for both the high- and low-density cultures was approximately 5:1.

\section{Pharmacological studies}

Experiments designed to measure the effects of cytoskeleton destabilizers were initiated by treating high-density $\mathrm{C} 6$ cultures $\left(6 \times 10^{3}\right.$ cells/ $\mathrm{mm}^{2}$ ) for $1 \mathrm{hr}$ at $37^{\circ} \mathrm{C}$, with $10^{-5} \mathrm{M}$ concentrations of either colchicine, nocodazole, or cytochalasin B (Sigma). Control cultures were treated under identical conditions with $0.003 \%$ dimethyl sulfoxide (DMSO). At the appropriate time, the cultures were extracted with buffer $A$, and detergent-soluble and cytoskeletal fractions were prepared as described above. 


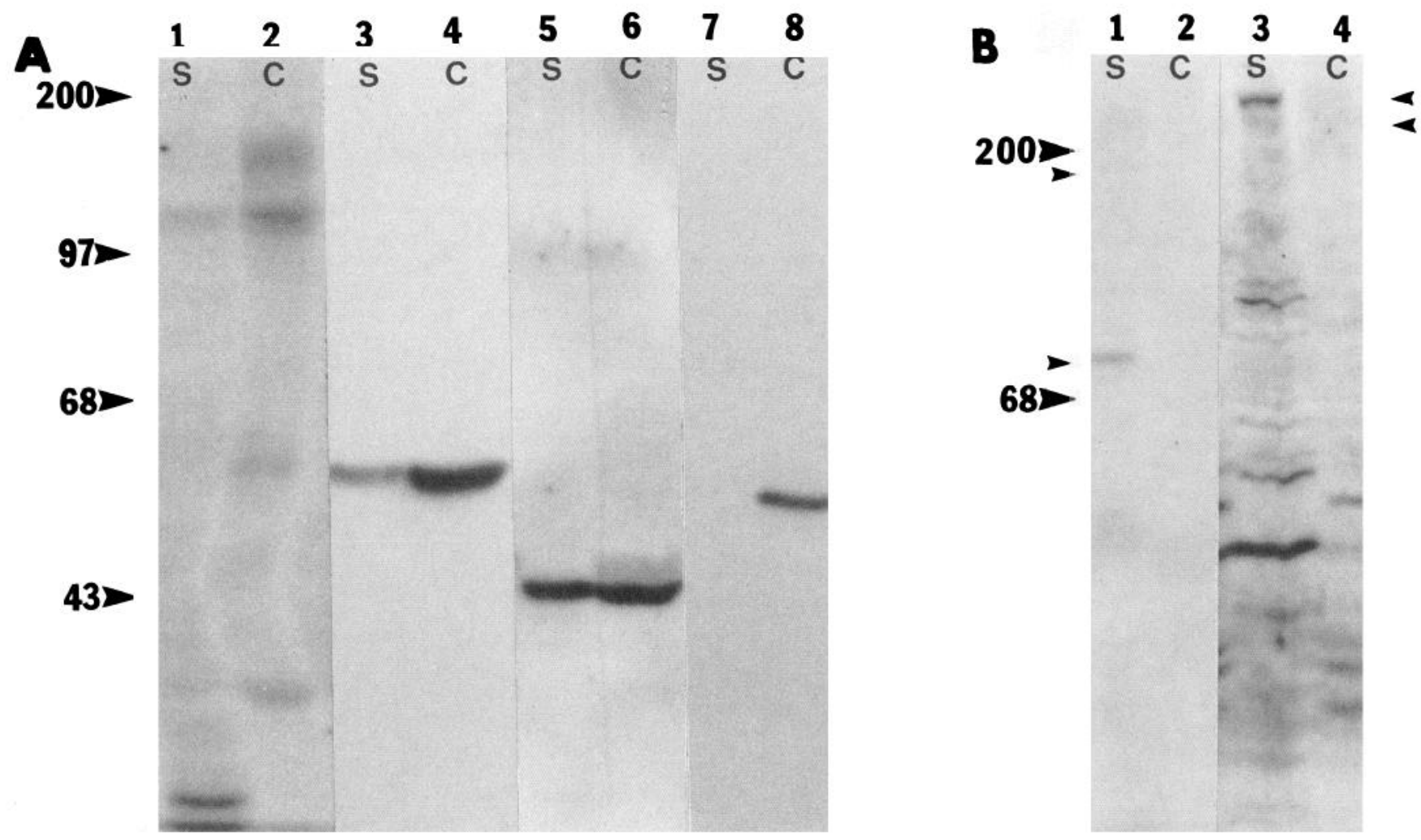

Figure 1. Immunoblot analysis of detergent-soluble and -insoluble fractions prepared from C6 glioma cell cultures. Cell fractions were prepared from high-density cultures $\left(5 \times 10^{5}\right.$ cells $\left./ \mathrm{mm}^{2}\right)$ in buffer A, as described in Materials and Methods. $A$, Immunoblots containing detergent-soluble $(S)$ or -insoluble $(C)$ fractions were probed with antisera against the following proteins: APP, lanes 1 and $2 ; \beta$-tubulin, lanes 3 and 4 ; actin, lanes 5 and 6 , and GFAP, lanes 7 and $8 . B$, Detergent-soluble $(S)$ or -insoluble $(C)$ fractions were probed with anti-Na $\mathrm{a}^{+} / \mathrm{K}^{+}-\mathrm{ATPase}($ lanes 1 and 2$)$ or anti-mannose-6-phosphate receptor (lanes 3 and 4) antisera. The small arrowheads next to lane 1 indicate the positions of the Na ${ }^{+} / \mathrm{K}^{+}-\mathrm{ATPase}$ $\alpha$-subunit ( $160 \mathrm{kDa})$ and $\beta$-subunit (75 kDa). The positions for the mannose-6-phosphate receptor at about $250 \mathrm{kDa}$ (Kiess et al., 1987) are indicated by the small arrowheads next to lane 4. For more details, see Materials and Methods.

High-density C6 cultures were treated, for $1 \mathrm{hr}$ at $37 \%$, with either $10^{-6} \mathrm{M}$ or $10^{-5} \mathrm{M}$ concentrations of the protein kinase $\mathrm{C}$ inhibitor staurosporine (Boehringer Mannheim). Control cultures were treated with $0.01 \%$ DMSO. Cells were extracted with buffer A, and soluble and cytoskeletal fractions were prepared.

In experiments designed to measure the effects of phorbol ester, lowdensity cultures $\left(4 \times 10^{2}\right.$ cells $\left./ \mathrm{mm}^{2}\right)$ were treated with $100 \mathrm{ng} / \mathrm{ml}$ phorbol 12-myristate 13-acetate (PMA; Sigma) for either 5 or $20 \mathrm{~min}$ at $37^{\circ} \mathrm{C}$. Control cultures were treated with $0.005 \%$ DMSO for $20 \mathrm{~min}$. Cells were extracted as described above.

\section{Results}

APP is associated with the detergent-insoluble cytoskeleton of brain and cell cultures

To investigate further the cytoskeletal association of APP, we extracted cell cultures and brain tissue with detergent-containing buffers. This methodology has been used extensively for the identification of integral membrane proteins bound to the cytoskeleton, including gP130, gP180, gP85, and E-cadherin (Lehto, 1983; Tarone et al., 1984; Bourguignon et al., 1985; Nelson et al., 1990). Cultures of the rat glioma cell line C6 (Benda et al., 1968) were extracted with CSK buffer containing the nonionic detergent Triton X-100 (buffer A; see Materials and Methods). Fractionation with this buffer yields a detergent-soluble fraction, containing most of the cytosolic and membrane-associated proteins, and a detergent-insoluble, cytoskeletal residue (Brown et al., 1976; Osborn and Weber, 1977; Sheetz, 1979).
This procedure has been shown to preserve the structural integrity of the major cytoskeletal elements, for example, microfilaments, microtubules, and intermediate filaments (Schliwa and Van Blerkom, 1981; Wilson and Brophy, 1989). Immunoblots of the soluble fraction and the cytoskeletal residue were probed with anti-R1 antibody, which is directed against the cytoplasmic domain of all APP forms (Anderson et al., 1989; Refolo et al., 1989). Figure $1 A$ (lanes 1 and 2) shows that in C6 cells two APP species are detected at about $M_{r} 110$ and 140 $\mathrm{kDa}$ and that both of these forms are associated with the cytoskeleton. Quantitation of the signals shown in Figure 1 (see Materials and Methods) indicated that approximately $85 \%$ of the total APP was found in the cytoskeletal residue. To verify the quality of our cytoskeletal preparations, we stained our blots with antisera against the following proteins: (1) $\beta$-tubulin, a component of the microtubules (Geiger, 1983); (2) actin, a component of microfilaments (Geiger et al., 1983); and (3) GFAP, a component of intermediate filaments (Steinert and Roop, 1988). As shown in Figure 1 (lanes 3-8), GFAP was found only in the insoluble residue, indicating that the extraction buffer maintains the integrity of the intermediate filaments (Lazarides, 1980). As expected, actin was equally distributed between soluble and insoluble fractions, while tubulin was found predominantly in the cytoskeletal fraction (Wilson and Brophy, 1989). To exclude the possibility that the cytoskeletal fractions were contaminated by intrinsic membrane proteins, we determined the partitioning 
of $\mathrm{Na}^{+} / \mathrm{K}^{+}$-ATPase, a well-characterized integral plasma membrane protein (Quigley and Gotterer, 1969), and mannose-6phosphate receptor, a membrane protein located predominantly in the Golgi apparatus and lysosomes (Willingham et al., 1983; Geuze et al., 1984). It can be seen in Figure $1 B$ that both of these proteins were found solely in the soluble fraction. Our results indicate that APP is associated with the detergent-insoluble cytoskeleton of a glial cell line under conditions that completely extracted other integral membrane proteins. To examine further the effects of our extraction conditions on the cytoskeletal association of APP, C6 cultures were extracted with TNE buffer (see Materials and Methods) in the presence of $0.5 \%$ Triton X-100. Extraction with this buffer also disrupts the cytoskeleton as it solubilizes most of the tubulin and actin (Fig. 2 , lanes 3-6). Under these conditions, more than $95 \%$ of the APP was found in the soluble fraction (Fig. 2, lanes 1 and 2), in agreement with the suggestion that the detergent-insoluble APP reflects its association with the intact cytoskeleton.

To determine if APP is associated with the cytoskeleton of neuronal cells, we prepared Triton X-100 soluble and insoluble extracts from PC12 cells grown in the presence of NGF (Greene and Tischler, 1982). Figure 3 (lanes 1 and 2) shows that more than $50 \%$ of the total APP was found in the detergent-insoluble fraction. In the same preparations, greater than $95 \%$ of the 160 kDa neurofilament subunit (NFM), a component of the neuronal cytoskeleton (Liem et al., 1978), was found in the detergentinsoluble fraction, while tubulin was distributed between the soluble and cytoskeletal fraction (Fig. 3, lanes 3-6). Furthermore, the NGFR, an intrinsic plasma membrane protein (Chao et al., 1986); synaptophysin, a membrane protein present in synaptic vesicles (Sudhof et al., 1987); and chromogranin B, found in secretory dense vesicles (Settleman et al., 1985); were extracted into the detergent-soluble fraction (Fig. 3, lanes 7-12). These data demonstrate that a significant percentage of the total APP is associated with the detergent-insoluble cytoskeleton of neuronal PC12 cells, under conditions that other integral membrane- or vesicle-associated proteins are extracted in the soluble fraction.

Detergent-soluble and -insoluble fractions were also prepared from rat brain. Approximately $35 \%$ of the total APP remained in the cytoskeletal residue after extraction with buffer A (Fig. 4, lanes 1 and 2). In the same preparations, greater than $95 \%$ of GFAP and NFM were found in the cytoskeletal residue (Fig. 4, lanes 3-6), while both $\mathrm{Na}^{+} / \mathrm{K}^{+}$-ATPase and synaptophysin were found in the soluble fraction (Fig. 4, lanes 7-10). These data demonstrate that a significant fraction of total brain APP is associated with detergent-insoluble cytoskeleton.

\section{Both cell surface and intracellular APP are bound to the cytoskeleton}

It has been reported that a fraction of the total cellular APP is on the cell surface (Weidemann et al., 1989). In addition, recent evidence suggested that a substantial amount of APP is located intracellularly (Berkenbosch et al., 1990; Catterucia et al., 1990). To determine if cell surface APP is associated with the cytoskeleton, C6 glioma cell cultures were labeled at the cell surface using lactoperoxidase/ $\mathrm{Na}^{125} \mathrm{I}$ followed by extraction with buffer $\mathrm{A}$ and immunoprecipitation of the labeled APP. It can be seen in Figure 5 that cell surface labeling resulted in the detection of only one APP isoform at $140 \mathrm{kDa}$, suggesting that at least a fraction of this protein is on the cell surface. In addition, most of the cell surface $140 \mathrm{kDa}$ APP was associated with the cyto-

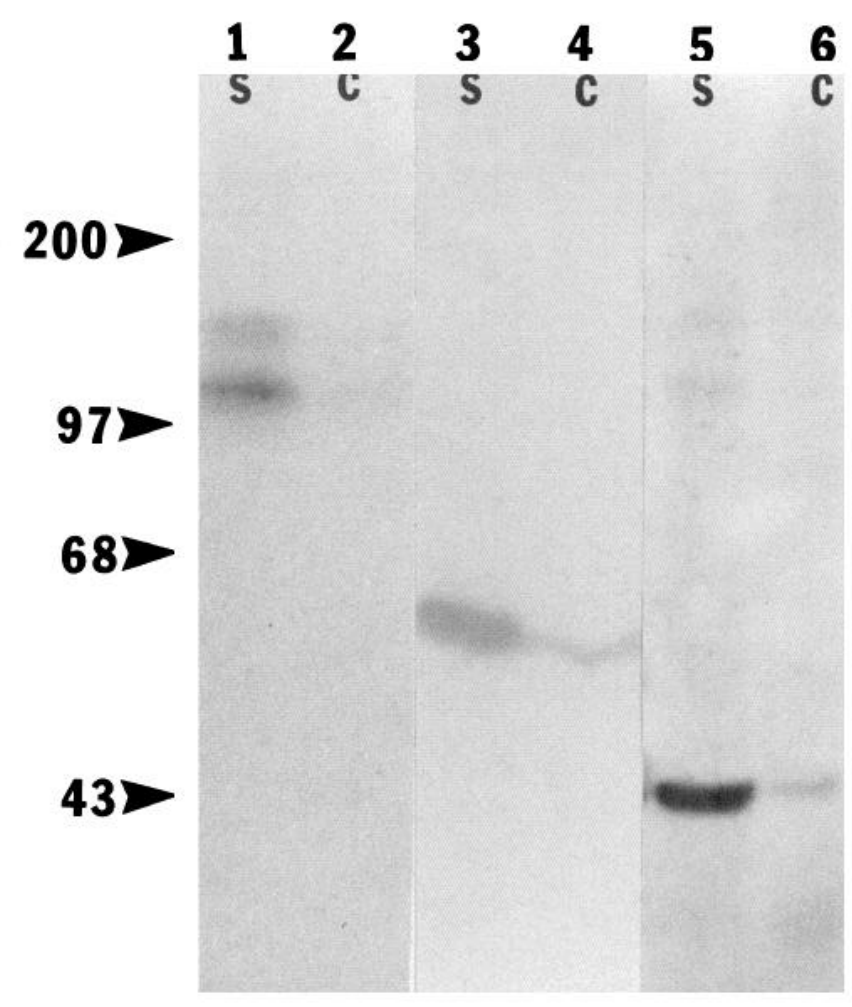

Figure 2. Immunoblot analysis of detergent-soluble $(S)$ or -insoluble (C) fractions prepared in TNE buffer from C6 glioma cells (see Materials and Methods). Filters were stained with the following antisera: AntiAPP, lanes 1 and 2 ; anti- $\beta$-tubulin, lanes 3 and 4 ; and anti-actin, lanes 5 and 6 .

skeletal residue, while gP96, a cell surface integral membrane protein (Maki et al., 1990), was found almost exclusively in the soluble fraction. Treatment of our cultures with trypsin resulted in the degradation of the ${ }^{125} \mathrm{I}$-labeled APP, confirming its cell surface localization (Fig. 5, lanes 7 and 8). Since only the 140 $\mathrm{kDa}$ band appears on the cell surface, we assume that the cytoskeletally associated $110 \mathrm{kDa}$ APP is intracellular. These results suggest that both cell surface and intracellular APPs are associated with the cytoskeleton.

\section{The cytoskeletal association of APP is modulated by cell density}

Previous studies have shown that increased cell-cell contact induces the reorganization of cytoskeletal elements, including ankyrin and fodrin complexes linked to integral membrane proteins such as E-cadherin (Marchesi, 1985; Nelson and Lazarides, 1985; Nelson et al., 1990). These cytoskeletal reorganizations may be reflected in the changes of the distribution of several integral membrane glycoproteins between the detergent-soluble and detergent-insoluble cytoskeletal fractions (Nelson and Veshnock, 1987). To examine the effects of cell density on the cytoskeletal association of APP, we prepared fractions from C6 cell cultures of varying cell density. Variations in cell density were achieved by two different methods (as described in Materials and Methods). Results obtained from method 1 showed a significant increase in the amount of cytoskeletal APP with increasing cell density. At low density, approximately $50 \%$ of the total APP was bound to the cytoskeleton, while at high density this value was more than $85 \%$ (Fig. $6 \mathrm{~A}$ ). Using method 


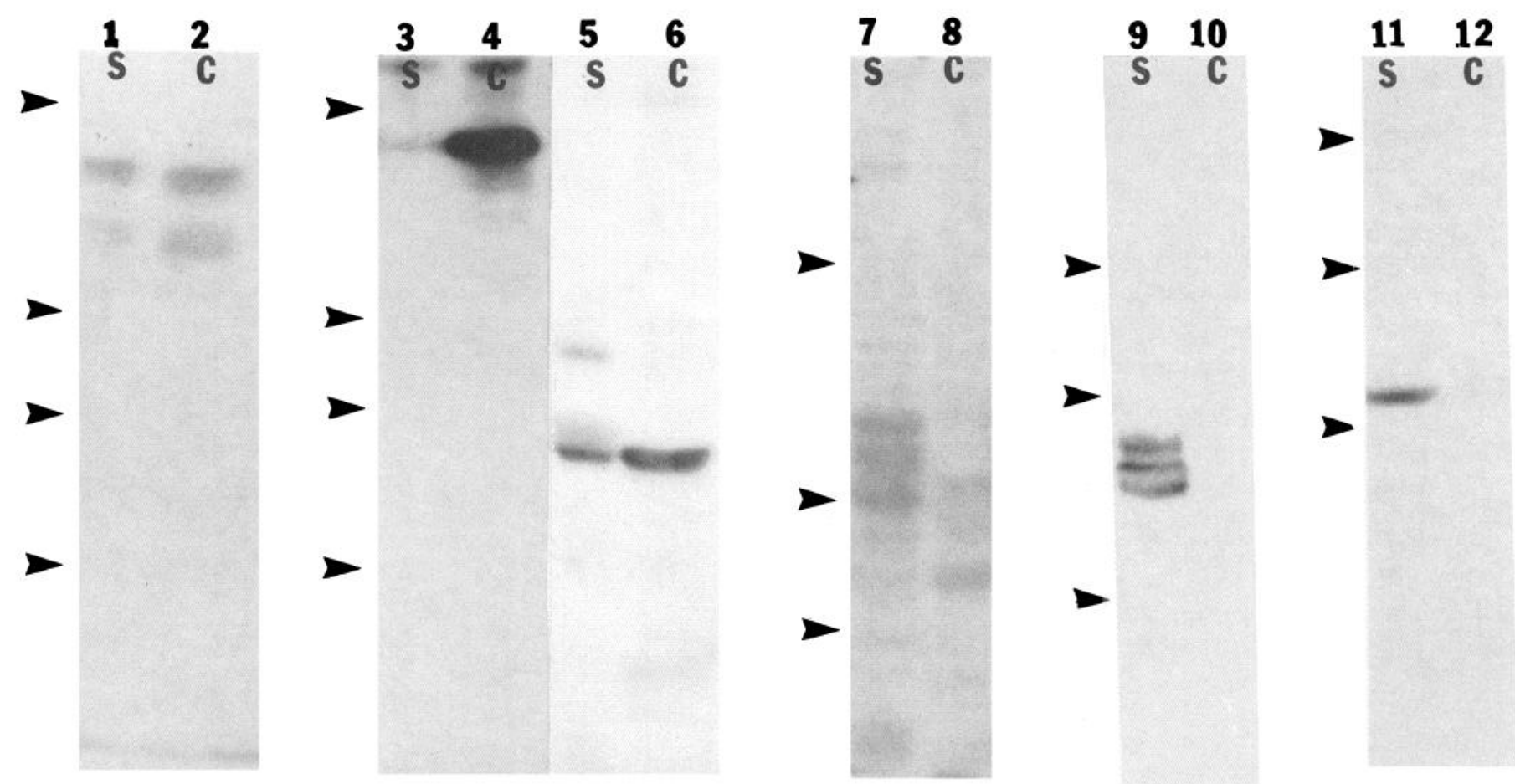

Figure 3. Immunoblots of detergent-soluble $(S)$ or -insoluble $(C)$ fractions prepared from neuronal PC12 cells in buffer A. Filters were stained with the following antisera: Anti-APP, lanes 1 and 2; anti-NFM, lanes 3 and 4; anti-tubulin, lanes 5 and 6 ; anti-NGFR, lanes 7 and 8 ; antisynaptophysin, lanes 9 and 10; and chromagranin B, lanes 11 and 12 . The arrowheads indicate the positions, from top to bottom, of molecular mass markers in $\mathrm{kDa}$ as follows. Lanes 1 and 2: 200, 97, 68, 43; lanes 3-6: 200, 97, 68, 43; lanes 7 and 8: 200, 97, 68; lanes 9 and 10: 68, 43, 29; lanes 11 and 12: 200, 97, 68. NGFR in lane 7 migrates between $M_{r}, 95$ and 120.

Figure 4. Immunoblots of detergentsoluble $(S)$ or -insoluble $(C)$ fractions prepared from rat brain in buffer $A$. Filters were stained with the following antisera: Anti-APP, lanes 1 and 2; antiGFAP, lanes 3 and 4; NFM, lanes 5 and 6 ; anti- $\mathrm{Na}^{+} / \mathrm{K}^{+}-\mathrm{ATPase}$, lanes 7 and 8 ; anti-synaptophysin, lanes 9 and 10. Arrowheads indicate the position of the molecular mass markers in $\mathrm{kDa}$.

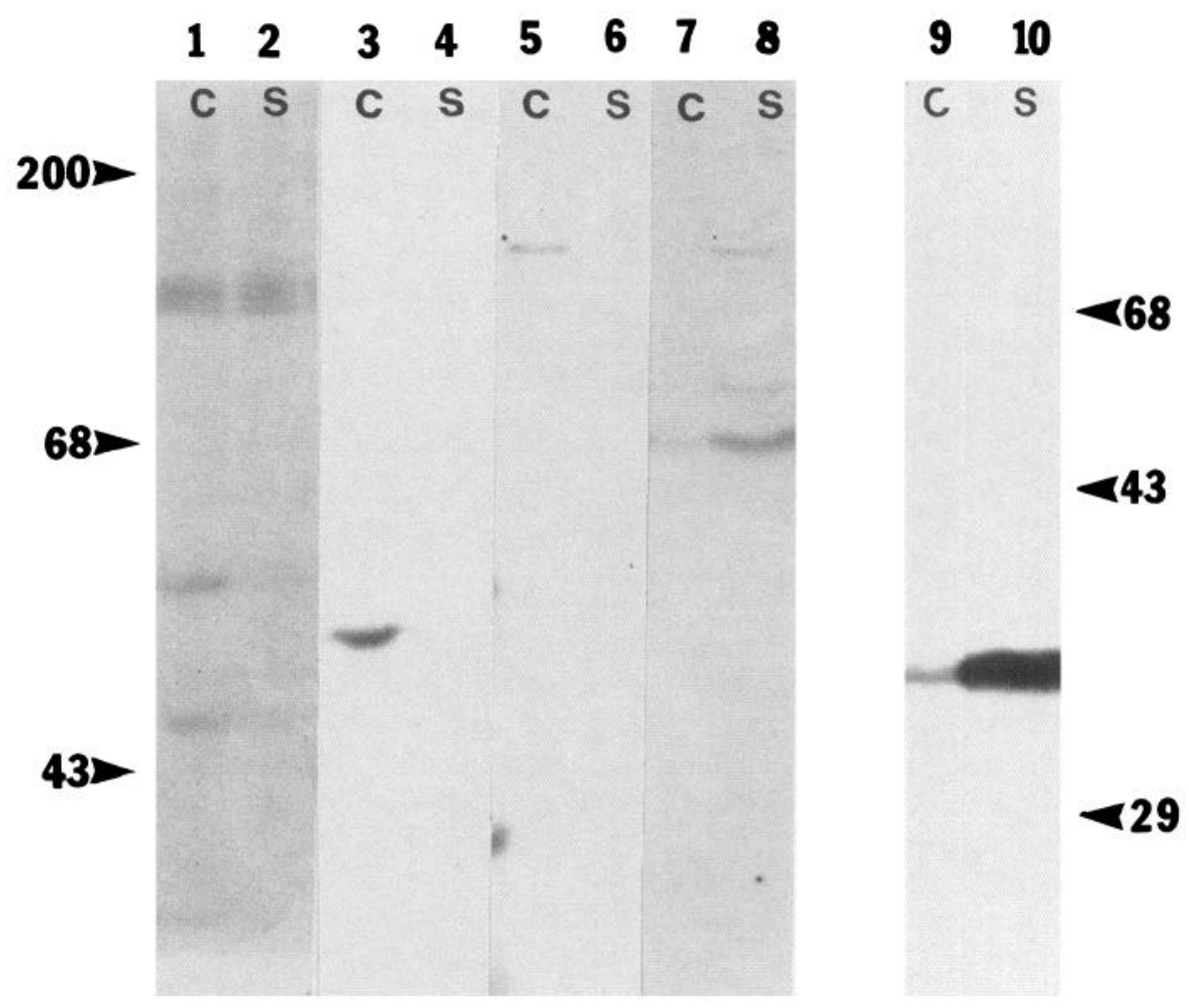




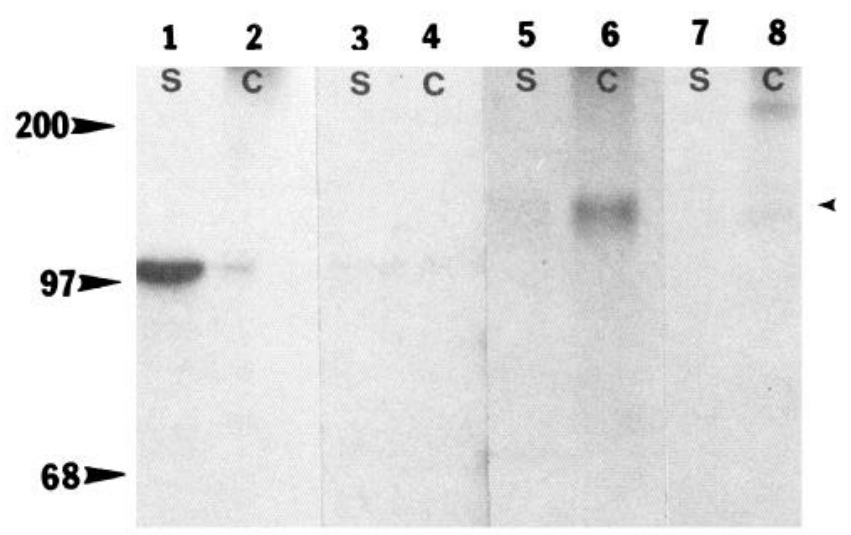

Figure 5. Immunoprecipitations of detergent-soluble $(S)$ or -insoluble (C) samples prepared in buffer A from C6 glioma cultures. Cell surface proteins were labeled with ${ }^{125} \mathrm{I}$, and samples from control (lanes 1, 2, 5 , and 6 ) or trypsin-treated (lanes $3,4,7$, and 8 ) cultures were immunoprecipitated with either anti-gP96 antisera (lanes 1-4) or anti-APP antisera (lanes 5-8). The small arrowhead indicates the position of the $140 \mathrm{kDa}$ APP band. For details, see Materials and Methods.

2, a similar trend was observed; at low density the level of cytoskeletal APP was approximately $60 \%$, while at high density this value increased to approximately $90 \%$ (Fig. $6 \mathrm{~B}$ ). Thus, in C6 cultures, the level of cytoskeleton-associated APP is modulated by cell density.

\section{The cytoskeletal association of APP requires intact microtubules}

To assess the role of specific cytoskeletal elements in the association of APP with the cytoskeleton, colchicine or nocodazole, which disrupt microtubules (Kirschner, 1978; Cassimeris et al., 1986), and cytochalasin B, which disrupts microfilaments (Weihing, 1976), were tested for their effects on the cytoskeletal distribution of APP in C6 cells (Fig. 7A). Treatment with colchicine decreased the amount of APP in the detergent-insoluble fraction from approximately $85 \%$ to $20 \%$ of the total APP (Fig. $7 A$, lanes 3 and 4). Nocodazole reduced the amount of detergentinsoluble APP to approximately $40 \%$ and therefore gave results qualitatively similar to colchicine (Fig. $7 A$, lanes 5 and 6 ). In contrast, the microfilament destabilizer cytochalasin B did not affect the distribution of APP (Fig. 7A, lanes 7 and 8). As expected, treatment with either of the microtubule destabilizers resulted in a significant increase in the amount of detergentsoluble $\beta$-tubulin (Fig. $7 B$ ), while treatment of cells with the microfilament destabilizer resulted in a large increase in the levels of detergent-soluble actin (data not shown). These results demonstrate that the association of APP with the cytoskeleton depends on the integrity of the microtubule network but does not depend on intact microfilaments.

\section{The cytoskeletal association of APP is modulated by protein phosphorylation}

Protein phosphorylation plays a major role in the regulation of cytoskeletal protein interactions (Vallee, 1980; Huang et al., 1984; Sihang et al., 1985; Baudier et al., 1987; Cianci et al., 1988; Husain-Chisti et al., 1988), and protein kinases have been implicated in the phosphorylation of APP (Gandy et al., 1988; Buxbaum et al., 1990). Consequently, we examined the relationship between protein kinase activity and the amount of APP associated with the detergent-insoluble cytoskeleton. Extracts were prepared from $\mathrm{C} 6$ cultures grown in the presence of staurosporine, a potent inhibitor of protein kinase $\mathrm{C}$, tyrosine kinase, and protein kinase A (Tamaoki et al., 1986; Nakano et al., 1987). As shown in Figure $8 A$, staurosporine decreased the levels of the cytoskeleton-associated APP in a concentration-dependent manner. At $10^{-5} \mathrm{M}$ staurosporine, approximately $25 \%$ of the total APP was found in the detergent-insoluble fraction, compared to greater than $85 \%$ in the control extracts, while at $10^{-6}$ $\mathrm{M}$ there was no difference compared to the control. Treatment of low-density C6 cultures with PMA, which stimulates protein kinase C (Huang, 1989), resulted in an increase in the amount of APP associated with the cytoskeletal fraction. At $100 \mathrm{ng} / \mathrm{ml}$ PMA, the level of cytoskeleton-associated APP increased after $5 \mathrm{~min}$ from the control level of $50 \%$ to more than $70 \%$. After 20 min of PMA treatment, the level of cytoskeletal APP increased to approximately $90 \%$ of the total (Fig. $8 B$ ). Taken together, these data indicate that stimulation of protein kinase activity increases the amount of cytoskeletal APP, while inhibition of this activity reduces the amount of cytoskeletal APP.


Figure 6. Changes in cell density modulate the levels of cytoskeletal APP. A, Method 1: C6 cultures were seeded at $1.3 \times 10^{2}$ cells $/ \mathrm{mm}^{2}$ and maintained for the required time until they reached the appropriate density, determined by trypsinizing and by counting sister cultures. Low-density cultures were obtained $1 \mathrm{~d}$ after plating and contained $4 \times 10^{2}$ cells $/ \mathrm{mm}^{2}$ (lanes 3 and 4 ). High-density cultures were obtained $5 \mathrm{~d}$ after plating and contained $6.3 \times 10^{3}$ cells $/ \mathrm{mm}^{2}$ (lanes 1 and 2 ). B. Method 2: low-density cultures were seeded at 50 cells $/ \mathrm{mm}^{2}$ and maintained for $4 \mathrm{~d}$, at which time they contained $6 \times 10^{2}$ cells $/ \mathrm{mm}^{2}$ (lanes 3 and 4). High-density cultures were seeded at $8 \times 10^{2}$ cells $/ \mathrm{mm}^{2}$ and maintained for $4 \mathrm{~d}$, at which time they contained $7 \times 10^{3}$ cells/ $\mathrm{mm}^{2}$ (lanes 1 and 2 ). At the appropriate density, cultures were extracted with buffer A, and detergentsoluble $(S)$ or -insoluble $(C)$ fractions were analyzed by Western blots using anti-APP antiserum. 


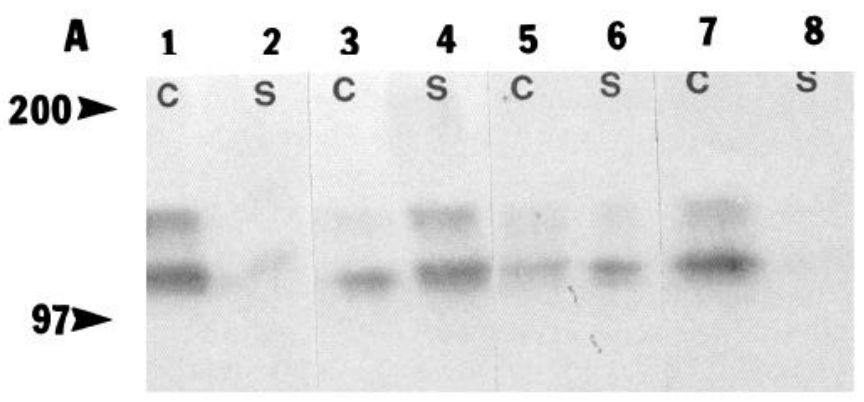

B

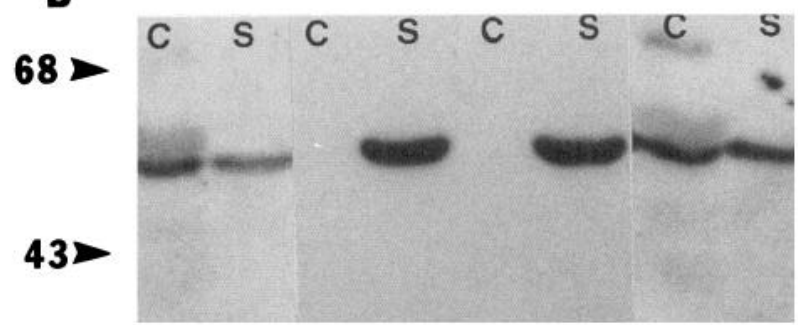

Figure 7. The effects of cytoskeleton destabilizers on the levels of cytoskeletal APP. $A$, High-density cultures $\left(6 \times 10^{3}\right.$ cells $\left./ \mathrm{mm}^{2}\right)$ were treated for $1 \mathrm{hr}$ with $10^{-5} \mathrm{M}$ concentrations of either colchicine, nocodazole, or cytochalasin B. Control cultures were treated with $0.003 \%$ DMSO. Cells were extracted with buffer $\mathrm{A}$, and detergent-insoluble $(C)$ or -soluble $(S)$ proteins were analyzed using anti-R1 antiserum. Lanes 1 and 2, control; lanes 3 and 4 , colchicine; lanes 5 and 6 , nocodazole; and lanes 7 and 8 , cytochalasin B. B, Same cell extracts as in $A$ probed with anti- $\beta$-tubulin.

\section{Discussion}

The results presented here demonstrate that APP is associated with the detergent-insoluble cytoskeleton of brain and of neuronal and glial cell lines. In a glial cell line, we found that both cell surface and intracellular APPs are associated with the cytoskeletal residue. Moreover, this association requires intact microtubules and is modulated by both cell density and protein phosphorylation.

We suggest that the cytoskeletal association of the APPs reflects specific protein interactions that are required to fulfill the biological function(s) of these proteins. There are many examples of integral membrane proteins that are functionally associated with the cytoskeleton. For example, the epidermal growth factor receptor (EGFR) has been found tightly associated with the detergent-insoluble cytoskeleton of a human carcinoma cell line A432 (Landreth et al., 1985). The association of the EGFR with the cytoskeleton is believed to be important for ligandstimulated autophosphorylation and internalization (Landreth et al., 1985). Another example for the functional significance of the cytoskeletal association of an integral membrane protein is the cell adhesion molecule cadherin E (uvomorulin), which modulates cell-cell interactions by forming specific sites of contact (junctional complexes) with the cytoskeletal proteins ankyrin and fodrin (Marchesi, 1985; Nelson and Lazarides, 1985; Nelson et al., 1990). In addition, recent studies indicate that the integrins, a family of cell surface glycoproteins, participate in cell-cell or cell-substratum interactions by linking cells to the substratum or to other cells via specific complexes with the cytoskeleton (Buck and Horwitz, 1987; Hynes, 1987; Burn et
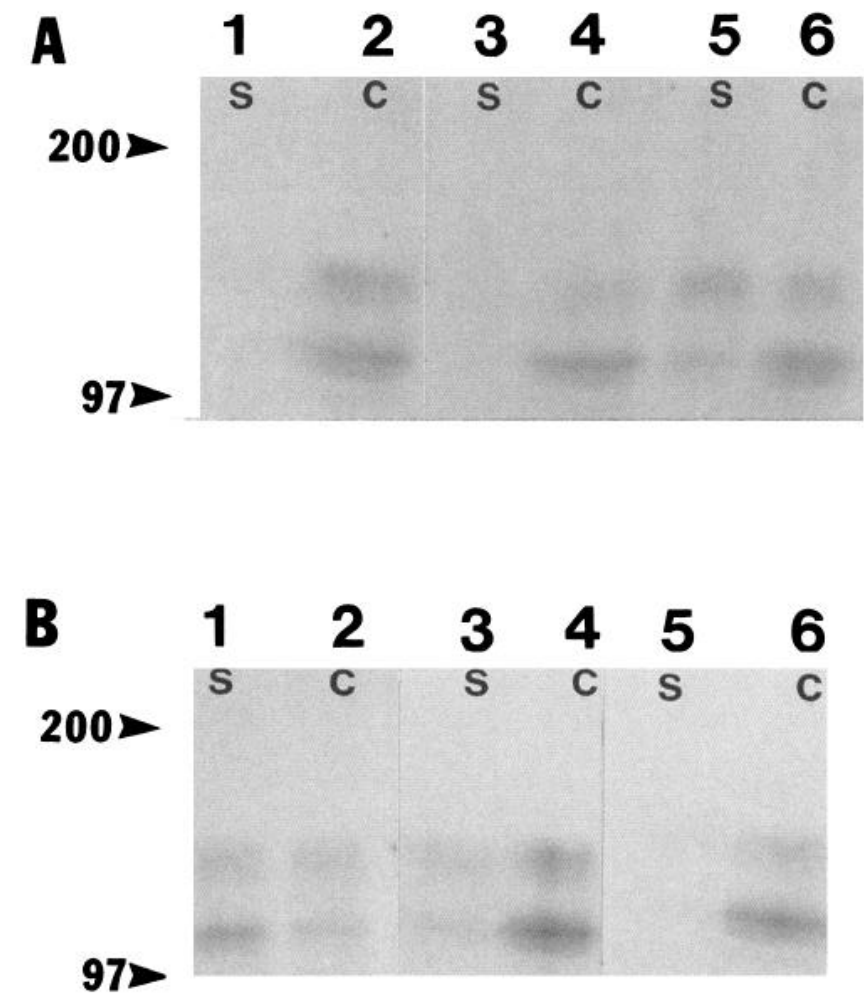

Figure 8. A, Effects of the protein kinase $\mathrm{C}$ inhibitor staurosporine on cytoskeletal APP. High-density cultures $\left(6 \times 10^{3} \mathrm{cells} / \mathrm{mm}^{2}\right)$ were treated for $1 \mathrm{hr}$ with either $10^{-5} \mathrm{M}$ or $10^{-6} \mathrm{M}$ staurosporine (Boehringer Mannheim). Control cultures were treated with $0.01 \%$ DMSO. Cells were extracted with buffer $\mathrm{A}$, and detergent-soluble $(S)$ or -insoluble $(C)$ proteins were analyzed by Western blots using anti-R1. Lanes $I$ and 2 , control fractions; lanes 3 and $4,10^{-7} \mathrm{M}$ staurosporine; lanes 5 and 6 , $10^{-6} \mathrm{M}$ staurosporine. $B$, Effects of phorbol ester on the cytoskeletal APP. Low-density cultures $\left(3 \times 10^{2}\right.$ cells $\left./ \mathrm{mm}^{2}\right)$ were treated with 100 $\mathrm{ng} / \mathrm{ml}$ of PMA for either 5 min (lanes 3 and 4 ) or 20 min (lanes 5 and 6). Control cultures were treated with $0.005 \%$ DMSO for 20 min (lanes 1 and 2). Cells were extracted and analyzed as in $A$.

al., 1988). These complexes are mediated by the cytoplasmic domain of the $\beta$-integrin, mutation of which disrupted the adhesion function of the integrins (Hayashi et al., 1990). Therefore, the cytoskeletal association of the cell surface APP may reflect its function as a cell-cell or cell-substratum adhesion molecule. These suggestions are further supported by recent experimental results indicating that APP may participate in cell adhesion events (Schubert et al., 1989; Breen et al., 1991).

The significance of the cytoskeletal association of the intracellular APP is less clear. However, the selective disruption of microtubules disrupted the cytoskeletal association of the intracellular APP. Depolymerization of microtubules results in the dispersal of cellular organelles including the Golgi apparatus, lysosomes, and the endoplasmic reticulum (Kelly, 1990). Since a fraction of the intracellular pool of APP will be located in these organelles, the effects of microtubule disruptors on APP detergent solubility might be the indirect result of this dispersal. An alternative hypothesis is that APP itself is physically anchored to microtubules, either directly or through some intermediary factors such as the microtubule-associated proteins. This association is likely to occur via the 47 amino acid C-terminal domain of APP, which is predicted to lie within the cytoplasm and therefore to be available for interaction with cytoskeletal proteins. 
Recent experimental evidence suggests that a significant fraction of the intracellular APP is located in vesicles (Van Nostrand et al., 1989; Catterucia et al., 1990; K. Sambamurti and N. K. Robakis, unpublished observations) and, in neurons, undergoes fast axonal transport (Koo et al., 1990). The microtubule network has been shown to play a major role in intracellular vesicular protein transport, including fast axonal transport (Grafstcin and Forman, 1980; Kelly, 1990). It is therefore plausible that intracellular APP is located in transport vesicles that are associated with the microtubule network, and in fact would link transport vesicles to microtubules.

The relative amount of the total APP bound to the cytoskeleton increases with increasing cell density in vitro. Increased contact among cells induces a number of cellular changes including development of cell polarity, reorganization of the cytoskeletal elements, synapse formation, and clustering of membrane proteins (Nelson and Lazarides, 1985). In addition, it has been shown that cell density may affect the stability of microtubules (Pepperkok et al., 1990). Therefore, the modulation of the cytoskeletal APP by cell density might be part of this reorganization and may suggest that APP plays a role in the cellular changes induced by cell density. Variations in the cytoskeletal association of APP may occur in the brain in response to changes in cell density, due to neuronal loss, that accompany the aging process.

Protein phosphorylation plays a major role in the regulation of cytoskeletal protein interactions including those of neurofilaments and microtubule-associated proteins (Vallee, 1980; Cianci et al., 1988; Husain-Chisti et al., 1988). In addition, protein kinase $C$ has been implicated in the control of junctional complexes and on the anchoring of $\alpha_{6}$-integrin subunit to the cytoskeleton (Burn et al., 1988; Shaw et al., 1990). The dependence of the cytoskeletal association of APP on protein kinase $C$ activity suggests that phosphorylation of APP itself (Oltersdorf et al., 1990) or of cytoskeletal protein(s) is required for the cytoskeletal anchoring of APP. Phosphorylation is believed to be the physiological mechanism regulating the interaction of other proteins to the cytoskeleton (Shaw et al., 1990) and may play a similar role for APP.

An important problem in understanding the pathophysiology of $\mathrm{AD}$ is the elucidation of the mechanisms that generate $\mathrm{A} \beta \mathrm{P}$. This peptide, which has been shown to be neurotoxic in primary cell cultures (Yankner et al., 1990), may arise from the aberrant proteolysis of APP as a result of abnormal posttranslational modifications (Warren et al., 1987) or intracellular trafficking. The normal trafficking and posttranslational processing of APP may require its association with the microtubules. Disruption of this process may lead to aberrant proteolytic processing and the production of amyloidogenic fragments of APP. This suggestion is supported by recent data indicating that disruption of the microtubule network results in decreased rates of transport and altered proteolytic processing of several other proteins, including cathepsin D (Scheel et al., 1990). Recently, an amino acid change in the transmembrane region of APP has been shown to segregate with familial AD (Goate et al., 1991). It would be interesting to determine whether this mutation interferes with the cytoskeletal association of APP. Recent evidence suggests that protein phosphorylation modulates the proteolysis of APP (Buxbaum et al., 1990). Since protein phosphorylation also modulates the levels of cytoskeletally associated APP, it is tempting to speculate that cytoskeletally anchored APP may provide a unique substrate for proteolysis. Recent studies show that, in AD brain, there is abnormal phosphorylation of cytoskeletal proteins, including tau, and low levels of protein kinase C (Grundke-Iqbal et al., 1986; Kosik et al., 1986; Cole et al., 1988; Bancher et al., 1989).

These observations raise the possibility that, in AD, abnormal protein phosphorylation alters the cytoskeletal association of APP and thereby triggers the events that lead to the production of $A \beta P$. Whether or not this hypothesis proves true, our results present a novel conceptual framework in which to analyze the biological function and pathological degradation of APP.

\section{References}

Anderson JP, Refolo LM, Wallace W, Mehta P, Krishnamurthi M Gotlib J, Bierer L, Haroutunian V, Perl D, Robakis NK (1989) Differential brain expression of the Alzheimer's amyloid precursor protein. EMBO J 8:3627-3632.

Anderson .IP, Esch FS, Keim PS, Sambamurti K, Leiberburg I, Robakis NK (1991) Exact cleavage site of Alzheimer amyloid precursor in neuronal PC-12 cells. Neurosci Lett 128:126-128.

Bancher C, Brunner C, Lassmann H, Budka H, Jellinger K, Wiche G Seitelberger F, Grundke-Iqbal I, Iqbal K, Wisniewski HM (1989) Accumulation of abnormally-phosphorylated tau precedes the formation of neurofibrillary tangles in Alzheimer's diseasc. Brain Res 477:90-96.

Baudier J, Lee S-H, Cole RD (1987) Separation of the different microtubule-associated tau protein species from bovine brain and their mode II phosphorylation by $\mathrm{Ca}^{++} /$phospholipid dependent protein kinase C. J Biol Chem 262:17584-17590.

Benda P, Lightbody L, Sato G, Levine L, Sweet W (1968) Differentiated rat glial cell strain in tissue culture. Science 161:370.

Berkenbosch F, Refolo LM, Friedrich VL, Casper D, Blum M, Robakis NK (1990) The Alzheimer's amyloid precursor protein is produced by type I astrocytes in primary cultures of rat neuroglia. J Neurosci Res 25:431-440.

Bourguignon LW, Suchard SJ, Nagpal ML, Glenney JR (1985) A T-lymphoma transmembrane glycoprotein (gp 180) is linked to the cytoskeletal protein fodrin. J Cell Biol 101:477-487.

Breen KC, Bruce M, Anderton BH (1991) Beta-amyloid precursor protein mediates neuronal cell-cell and cell surface adhesion. $J$ Neurosci Res 28:90-100.

Brown S, Levinson W, Spudich JA (1976) Cytoskeletal elements of chick embryo fibroblasts revealed by detergent extraction. J Supramol Struct 5:119-130.

Buck CA, Horwitz AF (1987) Integrin: a transmembrane glycoprotein complex mediating cell-substratum adhesion. J Cell Sci 8:231-250.

Burn P, Kupfer A, Singer SJ (1988) Dynamic membrane cytoskeleton interaction: specific association of integrin and talin arise in vivo after phorbol ester treatment of peripheral blood lymphocytes. Proc Natl Acad Sci USA 85:497-501.

Burridge K, Fath K, Kelly T, Nuckolls G, Turner C (1988) Focal adhesion: transmembrane junctions between the extracellular matrix and the cytoskeleton. Annu Rev Cell Biol 4:487-525.

Buxbaum JD, Gandy SE, Cicchetti P, Ehrlich ME, Czernik AJ, Fracasso RP, Ramabhadran TV, Unterbeck AJ, Greengard P (1990) Processing of Alzheimer $\beta / A 4$ amyloid precursor protein modulation by agents that regulate protein phosphorylation. Proc Natl Acad Sci USA 87:6003.

Cassimeris LU, Wadsworth P, Salmon ED (1986) Dynamics of microtubule depolymerization of monocytes. J Cell Biol 102:2023-2031.

Catterucia N, Willingale-Theune J, Bunke D, Prior R, Masters CL, Crisanti A, Beyreuther K (1990) Ultrastructural localization of the putative precursors of the A4 amyloid protein associated with Alzheimer's disease. Am J Pathol 137:19-26.

Chao MV, Bothwell MA, Ross AH, Koprowski H, Lanaham AA, Buck CR, Sehgal A (1986) Gene transfer and molecular cloning of the human NGF receptor. Science 232:418-423.

Cianci CD, Giorgi M, Morrow JS (1988) Phosphorylation of ankyrin regulates its cooperative interaction with spectrum and protein 3 . J Cell Biochem 37:301-312.

Cole G, Dobkins KR, Hansen L, Terry TD, Saitoh T (1988) Decreased levels of protein kinase C in Alzheimer brain. Brain Res 452:165174. 
Esch FS, Keim PS, Beattie EC, Blacher RW, Culwell AR, Oltersdorf T, McClure D, Ward PJ (1990) Cleavage of amyloid $\beta$ peptide during constitutive processing of its precursor. Science 248:1122-1124.

Gandy S, Czernik AJ, Greengard P (1988) Phosphorylation of Alzheimer disease amyloid precursor peptide by protein kinase $\mathrm{C}$ and $\mathrm{Ca}^{2+} /$ calmodulin-dependent protein kinase II. Proc Natl Acad Sci USA 85:6218-6223.

Geiger B (1983) Membrane-cytoskeleton interaction. Biochim Biophys Acta 737:305-341.

Geuze HJ, Slot JW, Straus GJ, Gaslik A, Von Figura E (1984) Ultrastructural localization of the mannose phosphate receptor in rat liver. J Cell Biol 18:2047-2054.

Goate A, Chartier-Harlin MC, Mullan M, Brown J, Crawford F, Fidani L, Giuffra L, Haynes A, Irving N, James L, Mant R, Newton P, Rooke $\mathrm{K}$, Roques P, Talbot C, Pericak-Vance M, Roses A, Williamson R, Rossor M, Owen M, Hardy J (1991) Segregation of a missense mutation in the amyloid precursor protein with familial Alzheimer's disease. Science 349:704-706.

Goldgaber D, Lerman JI, McBride OW, Saffiotti U, Gajdusek CD (1987) Isolation, characterization, and chromosomal localization of human brain cDNA clones coding for the precursor of the amyloid of brain in Alzheimer's disease, Down's syndrome, and aging. Science 235:877-881.

Gorbsky G, Steinberg MS (1981) Isolation of the intercellular glycoproteins of desmosomes. J Cell Biol 90:243-248.

Grafstein B, Forman D (1980) Intracellular transport in neurons. Physiol Rev 60:1167-1271.

Greene LA, Tischler AS (1982) PC 12 pheochromocytoma cultures in neurobiological research. Adv Cell Neurobiol 3:373-414.

Grundke-Iqbal I, Iqbal K, Tung YC, Quinlan M, Wisniewski HM, Binder LI (1986) Abnormal phosphorylation of the microtubule-associated protein tau (tau) in Alzheimer cytoskeletal pathology. Proc Natl Acad Sci USA 83:4913-4918.

Hayashi Y, Haimovich B, Reszka A, Boettiger D, Horwitz A (1990) Exprcssion and function of chicken integrin $\beta_{1}$ subunit and its cytoplasmic domain mutants in mouse NIH 3T3 cells. J Cell Biol 110 : 175-184.

Huang CK, Hill JM, Borman BJ, Mackip WM, Becken EL (1984) Chemotactic factors induce vimentin phosphorylation in rabbit peritoneal neutrophils. J Biol Chem 259:1386-1392.

Huang K-P (1989) The mechanism of protein kinase $\mathrm{C}$ activation. Trends Neurol Sci 12:425-429.

Hubbard SC, Cohn ZA (1976) Specific labels for cell surfaces. In: Biochemical analysis of membranes (Maddy AH, ed), pp 427-501. London: Clappman and Hall.

Husain-Chisti A, Levin A, Branton D (1988) Abolition of actin bundling by phosphorylation of human erythrocyte protein 4.9. Nature 334:718-721.

Hynes RO (1987) Intcgrins: a family of cell surface reccptors. Ccll 48: 549-554.

Kang J, Lemaire HG, Unterbeck A, Salbaum JM, Masters CL, Gzeschick KH, Multhap G, Beyreuther K, Muller-Hill B (1987) The precursor of Alzheimer's disease amyloid A4 protein resembles a cellsurface receptor. Nature 325:733-736.

Kelly RB (1990) Microtubules, membrane traffic, and cell organization. Cell 61:5-7.

Kiess W, Haskel JF, Lee L, Greenstein LA, Miller BE, Aarons AL, Rechler MM, Nissley PS (1987) An antibody that blocks insulinlike growth factor (IGF) binding to the type II IGF receptor is neither an agonist nor an inhibitor of IGF-stimulated biological responses in L6 myoblasts. J Biol Chem 462:12745-12751.

Kirschner MW (1978) Microtubule assembly and nucleation. Int Rev Cytol 54:1-71.

Kitaguchi N, Takahahi Y, Tokushima Y, Shiojiri S, Hirataka I (1988) Novel precursor of Alzheimer's disease amyloid protein shows protease inhibitory activity. Nature 331:530-534.

Koo EH, Sisodia SS, Archer DR, Martin LJ, Weidemann A, Beyreuther K, Fischer P, Masters CL, Price DL (1990) Precursor of amyloid protein in Alzheimer's disease undergoes fast anterograde axonal transport. Proc Natl Acad Sci USA 87:1561-1565.

Kosik K, Joachim C, Selkoe D (1986) Microtubule-associated protein tau (tau) is a major antigenic component of paired helical filaments in Alzheimer's disease. Proc Natl Acad Sci USA 83:4044-4049.

Landreth GE, Williams LK, Rieser GD (1985) Association of the epidermal growth factor receptor kinase with the detergent-insoluble cytoskeleton of A431 cells. J Cell Biol 101:1341-1350.
Lazarides E (1980) Intermediate filaments as mechanical integrations of cellular space. Nature 283:249-256.

Lehto VP (1983) 140,000 dalton surface glycoprotein: a plasma membrane component of the detergent-resistant cytoskeleton preparation of cultured human fibroblasts. Exp Cell Res 143:271-286.

Liem RKH, Yen S-U, Salomon GD, Shelanski ML (1978) Intermediate filaments in nervous tissues. J Ccll Biol 79:637-643.

Maki RG, Old LJ, Srivastava PK (1990) Human homologue of murine tumor rejection antigen gp96: 5'-regulatory and coding regions and relationship to stress-induced proteins. Proc Natl Acad Sci USA 87: 5658-5662.

Marchesi VT (1985) Stabilizing infrastructure of cell membranes. Annu Rev Cell Biol 1:531-562.

Nakano H, Kobayashi E, Takahashi I, Tamaoki T, Kuzuu Y, Iba H (1987) Staurosporine inhibits tyrosine-specific protein kinase activity of Rous sarcoma virus transforming protein p60. J Antibiot 40:706708.

Nelson WJ, Lazarides E (1985) Assembly and establishment of membrane-cytoskeletal domains during differentiation: spectrin as a model system. In: Cell membranes: methods and reviews, Vol 2 (Elson E, Frazicr W, Glascr L, cds), pp 219-246.

Nelson WJ, Veshnock PJ (1987) Modulation of fodrin (membrane skeleton) stability by cell-cell contact in Madin-Darby canine kidney epithelial cells. J Cell Biol 104:1527-1537.

Nelson WJ, Shore EM, Wang AZ, Hammerton RW (1990) Identifcation of a membrane-cytoskeletal complex containing the cell adhesion molecule uvomorulin (E. cadherin), ankyrin, and fodrin in Madin-Darby canine kidney epithelial cells. J Cell Biol 1 10:349-357.

Oltersdorf T, Ward P, Henriksson T, Beattie EC, Neve R, Liebergurg I, Fritz LC (1990) The Alzheimer's amyloid protein identification of a stable intermediate in the biosynthetic/degradative pathway. $J$ Biol Chem 265:4492-4497.

Osborn M, Weber K (1977) The detergent resistant cytoskeleton of tissue culture cells includes the nucleus and microfilament bundles. Exp Cell Res 106:339-349.

Pepperkok R, Bre MH, Davoust S, Kries TE (1990) Microtubules are stabilized in confluent epithelial cells but not in fibroblasts. J Cell Biol 111:3003-3012.

Pollerberg GE, Burridge K, Krelas KE, Goodman SR, Schachner M (1987) The $180 \mathrm{kD}$ component of the neural cell adhesion molecule $\mathrm{N}$-CAM is involved in cell-cell contacts and cytoskeleton-membrane interactions. Cell Tissue Res 250:227-236.

Ponte P, Gonzalez-DeWhitt P, Schilling J, Miller J, Hsu D, Greenberg B, Davis K, Wallace W, Lieberberg I, Fuller F, Cordell B (1988) A new A4 amyloid mRNA contains a domain homologous to serine proteinase inhibitors. Nature 331:525-527.

Quigley JP, Gotterer GS (1969) Distribution of $\mathrm{Na}^{++}-\mathrm{K}^{++}-$stimulated ATPase activity in rat intestinal mucosa. Biochim Biophys Acta 173: $456-463$.

Refolo LM, Salton SRJ, Anderson JP, Mehta P, Robakis NK (1989) Nerve and epidermal growth factors induce the release of the Alzheimer's amyloid precursor from PC12 cell cultures. Biochem Biophys Res Commun 164:664-670.

Robakis NK, Ramakrishna N, Wolfe G, Wisniewski HM (1987) Molecular cloning and characterization of a cDNA encoding the cerebrovascular and neuritic plaque amyloid peptides. Proc Natl Acad Sci USA 84:4190-4194.

Saitoh T, Sundsmo M, Roch JM, Kimura N, Cole G, Schubert D, Oltersdorf T, Schenk DB (1989) Secreted form of the amyloid $\beta$ protein precursor is involved in the growth regulation of fibroblasts. Cell 25:615-622.

Scheel J, Matteoni R, Ludwig T, Hoelack B, Kreis TE (1990) Microtubulc depolymcrization inhibits transport of cathcpsin $\mathrm{D}$ from Golgi apparatus to lysosomes. J Cell Sci 96:711-720.

Schliwa M, Van Blerkom J (1981) Structural interaction of cytoskeletal components. J Cell Biol 90:222-235.

Schubert D, LaCorbiere M, Saitoh T, Cole G (1989) Characterization of an amyloid beta precursor protein that bonds heparin and contains tyrosine sulfate. Proc Natl Acad Sci USA 86:2066-2071.

Settleman J, Fonseca R, Nolan J, Angeletti RH (1985) Relationships of multiple forms of chromogranin. J Biol Chem 260:1645-1651.

Shaw LM, Messier L, Mercurio AM (1990) The activation dependent adhesion of macrophages to laminin $I$ involves cytoskeletal anchoring and phosphorylation of the $\alpha_{6} \beta$, integrin. J Cell Biol 110:2167-2176.

Sheetz MP (1979) Integral membrane protein interaction with triton cytoskeleton of erythrocytes. Biochim Biophys Acta 557:122-134. 
Sihang RK, Jeng AY, Nixon RA (1985) Phosphorylation of neurofilament proteins by protein kinase C. FEBS Lett 233:181-186.

Siman R, Card JP, Davis LG (1990) Proteolytic processing of $\beta$-amyloid precursor by calpain 1 . J Neurosci 10:2400-2411.

Smith PK, Krohn RI, Hermanson GT, Mallia AK, Gartner FH, Provenzano MD, Fujimato EK, Goeke NM, Olson BJ, Klenk DC (1985) Measurement of protein using bicinchominic acid. Anal Biochem 150:76-85

Smith RP, Higuchi DA, Broze GJ (1990) Platelet coagulation factor $\mathrm{XI}$ inhibitor, a form of the Alzheimer's amyloid precursor protein. Science 248:1126-1128.

Steinert PM, Roop DR (1988) Molecular and cellular biology of intermediate filaments. Annu Rev Biochem 57:596-639.

Sudhof TC, Lottspeich F, Greengard P, Mehl E, Jahn R (1987) A synaptic vesicle protein with a novel cytoplasmic domain and four transmembrane regions. Science 238:1142-1144.

Tamaoki T, Namoto H, Takahashi I, Kato Y, Morimoto M, Tomita F (1986) Staurosporine, a potent inhibitor of phospholipid-Ca ${ }^{++}$-dependent protein kinase. Biochem Biophys Res Commun 135:397402.

Tanzi RE, Gusella JF, Watkins PC, Bruns GP, St George-Hyslop P, Van Keuren ML, Patterson D, Pajan S, Kurnit DM, Neve RL (1987) Amyloid beta protein gene: cDNA, mRNA distribution and genetic linkage near the Alzheimer's locus. Proc Natl Acad Sci USA 235: 880-884.

Tanzi RE, McClatchey AF, Lamberti ED, Villa-Kamaroff L, Gusella JF, Neve RL (1988) Protease inhibitor domain encoded by an amyloid protein precursor mRNA associated with Alzheimer's disease. Nature 331:528-530.
Tarone G, Ferrancini R, Galetto G, Comoglio P (1984) A cell surface integral membrane glycoprotein of $85 \mathrm{kD}$ (gp 85) is associated with the Triton X-100 insoluble cell-skeleton. J Cell Biol 99:512-519.

Vallee RB (1980) Structure and phosphorylation of microtubule-associated protein 2 (MAP-2). Proc Natl Acad Sci USA 77:3206-3210.

Van Nostrand WE, Wagner SL, Suzuki M, Choi BH, Farrow JS, Geddes JW, Cotman CW, Cunningham DD (1989) Protease nexin II, a potent anti-chymotrypsin, shows identity to amyloid beta-protein precursor. Nature 341:546-549.

Warren AC, Robakis NK, Ramakrishna N, Koo EH, Robb AS, Folstein MF, Price DL (1987) $\beta$-Amyloid gene is not present in three copies in autopsy-validated Alzheimer's disease. Genomics 1:307-312.

Weidemann A, Konig G, Bunke D, Fischer P, Salboum MJ, Masters CL, Beyreuther K (1989) Identification, biogenesis, and localization of precursors of Alzheimer's disease A4 amyloid protein. Cell 57: $115-126$.

Weihing RR (1976) Cytochalasin B inhibits actin-related gelation of HeLa cell extracts. J Cell Biol 71:303-314.

Willard M, Simon C (1981) Antibody decoration of neurofilaments. J Cell Biol 89:198-209.

Willingham MC, Pastan IM, Sahagian GG (1983) Ultrastructural immunocytochemical localization of the phosphomammosyl receptor in Chinese hamster ovary cells. J Histochem Cytochem 31:1-11.

Yankner B, Duffy LK, Kirschner DA (1990) Neurotrophic and neurotoxic effect of amyloid $\beta$ protein: reversal by tachykinin neuropeptides. Science 250:279-282.

Yu J, Fischman DA, Steck TL (1973) Selective solubilization of proteins and phospholipids from red blood cell membranes by non-ionic detergents. J Supramol Struct 1:233-248. 